\title{
The Cellular Functions of Eosinophils: Collegium Internationale Allergologicum (CIA) Update 2020
}

\author{
Hans-Uwe Simon ${ }^{a}$ b Shida Yousefia Nina Germic ${ }^{a}$ Isabelle C. Arnold ${ }^{c}$ \\ Angela Haczku ${ }^{d}$ Alexander V. Karaulov ${ }^{b}$ Dagmar Simon $^{e}$ \\ Helene F. Rosenberg ${ }^{f}$ \\ ${ }^{a}$ Institute of Pharmacology, University of Bern, Bern, Switzerland; ${ }^{b}$ Department of Clinical Immunology and \\ Allergology, Sechenov University, Moscow, Russia; ' Institute of Molecular Cancer Research, University of Zurich, \\ Zurich, Switzerland; dUniversity of California, Davis, Davis, CA, USA; ${ }^{e}$ Department of Dermatology, Inselspital, Bern \\ University Hospital, University of Bern, Bern, Switzerland; ${ }^{f}$ Laboratory of Allergic Diseases, National Institute of \\ Allergy and Infectious Diseases, National Institutes of Health, Bethesda, MD, USA
}

\section{Keywords}

Asthma · Eosinophils · Eosinophil cytolysis .

Eosinophil degranulation · Eosinophil extracellular traps ·

Hypereosinophilic syndromes · Inflammation · Interleukin-5 . Major basic protein - M2 macrophages - Mast cells .

Targeted therapy

\begin{abstract}
Eosinophils and their secretory mediators play an important role in the pathogenesis of infectious and inflammatory disorders. Although eosinophils are largely evolutionally conserved, their physiologic functions are not well understood. Given the availability of new eosinophil-targeted depletion therapies, there has been a renewed interest in understanding eosinophil biology as these strategies may result in secondary disorders when applied over long periods of time. Recent data suggest that eosinophils are not only involved in immunological effector functions but also carry out tissue protective and immunoregulatory functions that actively contribute to the maintenance of homeostasis. Prolonged eosinophil depletion may therefore result in the develop-
\end{abstract}

ment of secondary disorders. Here, we review recent literature pointing to important roles for eosinophils in promoting immune defense, antibody production, activation of adipose tissue, and tissue remodeling and fibrosis. We also reflect on patient data from clinical trials that feature antieosinophil therapeutics.

(c) 2019 S. Karger AG, Basel

Eosinophils, neutrophils and basophils, are subpopulations of granulocytes. Eosinophils were named by Paul Ehrlich in 1879 since these cells can be stained by the acidophilic dye eosin [1]. Eosinophils are present in all vertebrates, including zebrafish [2] and various species of reptiles [3], suggesting important physiologic functions which, however, remain largely unclear. A comprehensive understanding of eosinophil function is urgently needed given the development of novel targeted anti-eosinophil therapies that result in dramatic eosinopenia together with clearance of eosinophils from tissues. Spe-

Edited by: D.Y. Wang, Singapore.

\section{KARGER}

(c) 2019 S. Karger AG, Basel

E-Mail karger@karger.com

www.karger.com/iaa
Prof. Hans-Uwe Simon

Institute of Pharmacology

Inselspital, INO-F

$\mathrm{CH}-3010$ Bern (Switzerland)

E-Mail hus@pki.unibe.ch 
cifically, benralizumab, a therapeutic antibody directed against the IL-5 receptor $\alpha$-chain, eradicates eosinophils not only from blood but also from tissues [4]. An earlier evaluation concluded that there were no adverse consequences resulting from anti-eosinophil therapy [5]. However, we do not yet understand the consequences of eosinophil depletion and will need to determine whether patients who are fully devoid of eosinophils over a long period of time would be at risk for developing secondary disorders.

What is known is that eosinophils develop in bone marrow from myeloid precursors. For differentiation of eosinophils in response to allergic provocation, the cytokine IL-5 has been established as the critical mediator [6]. Interestingly, IL-5 also induces counter-regulatory mechanisms inhibiting eosinophil differentiation. For instance, IL-5 induces expression of the small G protein $\mathrm{RhoH}$ in immature eosinophils which ultimately reduces the rate of differentiation [7]. Other cytokines promoting eosinophil differentiation include IL-3 and GM-CSF [8]. Lineage commitment is controlled by an interplay of transcription factors that include GATA-1, GATA-2, PU.1, c/EBP- $\alpha$ [9] and XBP-1, a factor identified in granulocyte-macrophage and eosinophil progenitors that specifically promotes eosinophil maturation in mice [10].

Eosinophils are released into the circulation upon terminal differentiation and are recruited into tissues in response to chemokines, notably those of the eotaxin family $[11,12]$. Eosinophils are present for only a few hours in the blood [13] but can survive in tissues for several weeks [14]. Indeed, delayed apoptosis contributes to increased numbers of eosinophils in somatic tissues [15]. The number of eosinophils further increases under pathological conditions such as allergic or infectious/helminthic parasitic diseases. Blood hypereosinophilia is defined as more than 1,500 eosinophils $/ \mathrm{mm}^{3}$ [13]. Primary eosinophilic diseases are caused by genetic changes which affect the eosinophil lineage, while secondary eosinophilic diseases are caused by increased expression of one or more eosinophil hematopoietins [16]. Elevated levels of IL-3 and/or IL-5 are observed most often in eosinophilia associated with allergic responses and asthma [17]. By contrast, elevated GM-CSF levels more typically indicate the presence of a malignancy [18].

Eosinophils have been detected in all vertebrate species and are largely conserved from the perspective of morphology and general function. Notably, human and mouse eosinophils are distributed to similar sites throughout the body, maintain parallel (albeit not identical) developmental patterns, and display largely conserved re- sponses to Th2 cytokine provocation [19]. However, it is important to recognize that mouse and human eosinophils have unique features, with distinct cell surface receptors and granule components, as well as different propensities to degranulate in response to specific stimuli $[20,21]$. The eoCre mouse strain has facilitated introduction of human proteins into the mouse eosinophil lineage and may thus help to address this issue [22].

Owing to the availability of new experimental mouse models and to the novel, specific therapeutics that have been approved for human use, there has been significant recent progress in understanding the function of eosinophils in health and disease. Regarding the cellular characteristics of eosinophils, there are several excellent review articles available $[20,23]$. In this review article we will summarize new findings regarding eosinophil function, with a particular focus on their health promoting functions and their dysfunction in individual disease states.

\section{Eosinophil Degranulation and Eosinophil Extracellular Trap Formation}

The release of the content of granules into the extracellular space by activated eosinophils is termed piecemeal degranulation [24], which reflects the observation that usually only a small amount of the granule content is released and that eosinophils remain viable in this process (Fig. 1). Activated eosinophils develop cytoplasmic secretory vesicles (sombrero vesicles) and remain viable and fully responsive to subsequent stimuli, even if they are restimulated with the same ligands [25]. The process of exocytosis is observed less frequently as compared to piecemeal degranulation. Some activated eosinophils may undergo cytolysis (Fig. 1), a nonapoptotic form of eosinophil death which is observed in vivo $[26,27]$. Cytolysis of eosinophils results in the release of intact granules in the extracellular space [28]. The mechanism of eosinophil cytolysis involves components of the necroptotic pathway, including receptor-interacting protein kinase 3 (RIPK3) and mixed lineage kinase-like (MLKL) [29]. The extracellular deposition of eosinophil granule proteins in tissues as a sign of piecemeal degranulation under in vivo conditions can be detected by immunohistochemical and immunofluorescence techniques. Such investigations have demonstrated that eosinophil granule proteins are long-lived and even detectable after eosinophils have been removed in the process of resolution of inflammation [30].
Simon/Yousefi/Germic/Arnold/Haczku/ Karaulov/Simon/Rosenberg 


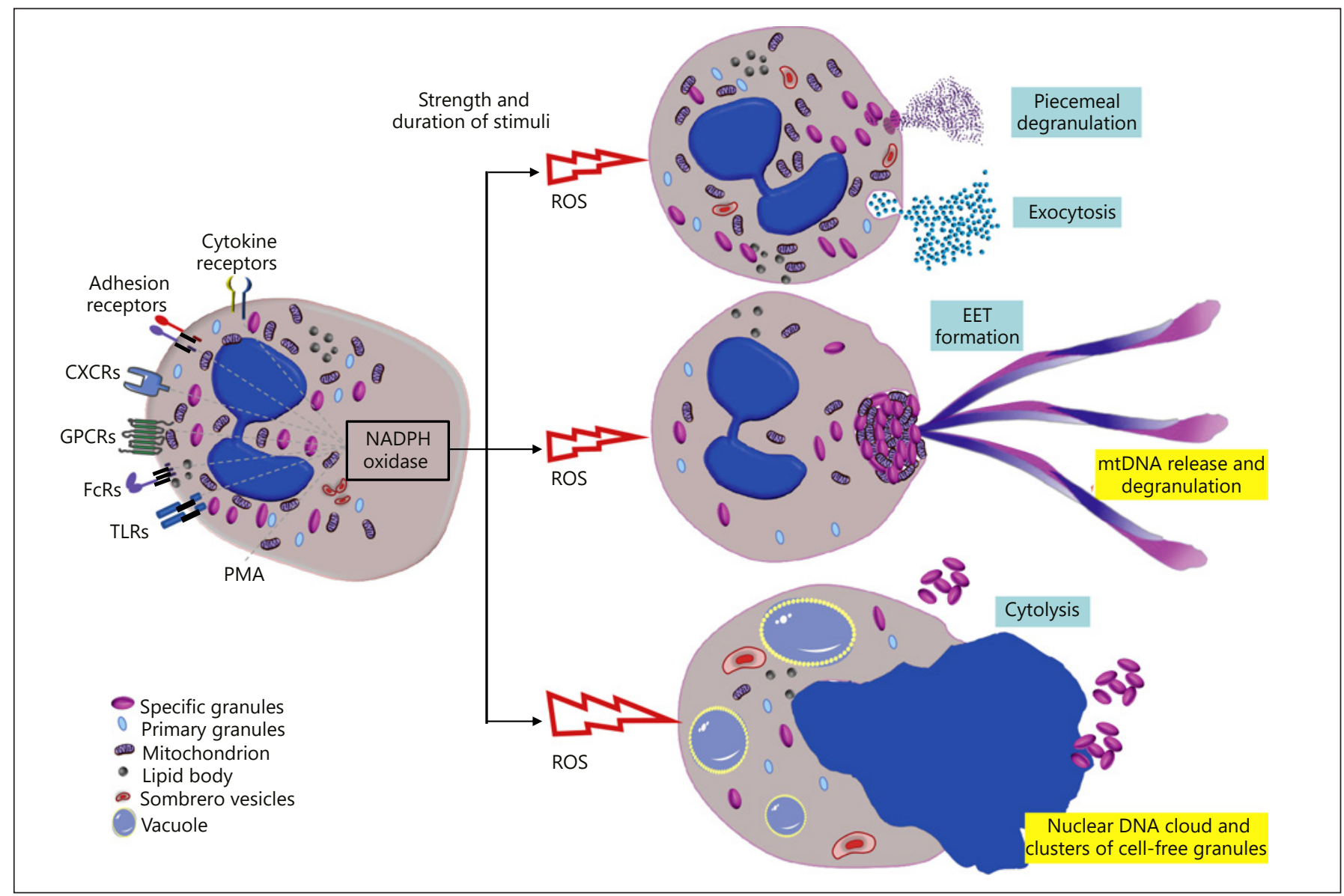

Fig. 1. Mediator release from eosinophils: degranulation, extracellular traps, and cytolysis. Schematic representation of functional responses leading to the release of secretory mediators. In response to physiologic stimuli, eosinophil assemble NADPH oxidase and release reactive oxygen species (ROS). Depending on the source, strength, and duration of the initial stimulus, eosinophils can degranulate, generate extracellular traps, or undergo cytolysis. Degranulation most typically occurs via piecemeal degranulation or exocytosis of mediators from the cytoplasmic granules as shown.

As eosinophil granule proteins can remain in tissues over weeks in the absence of severe damage, one can speculate that such proteins are somehow of limited toxicity. However, the granule proteins of eosinophils are cationic, they are released at high local concentrations from eosinophil cytoplasmic granules, and they have been demonstrated to be highly toxic to both pathogens and neighboring cells. It remains unclear how eosinophils can maintain control of the effects so that they themselves do not disintegrate from within. In the case of major basic protein (MBP), toxicity is regulated by functional aggregation and crystallization [31]; likewise, human ECP and EDN are complexed in granules with zinc [32].

The Cellular Functions of Eosinophils
Eosinophils can also form EET, which consist of a mitochondrial $(\mathrm{mt})$ DNA scaffold and cationic granule proteins. Cell activation above a certain threshold can lead to a nonapoptotic form of cell death, designated as cytolysis. During cytolysis cells form large vacuoles. The vacuoles, plasma, and nuclear membranes ultimately disintegrate, leading to release of the nuclear DNA as a virtual cloud. The release of extracellular clusters of cell-free granules is typically observed as a result of cytolysis.

Primary human eosinophil granules contain CharcotLeyden crystal protein (CLC, also known as galectin 10). In tissues characterized by eosinophilic infiltration, CLC crystals are often found in the extracellular space, suggesting a release from activated or cytolytic eosinophils [33]. CLC crystals stimulate Th2 immune responses, while a soluble CLC mutant form has been found to be inert [34]. An anti-CLC antibody against epitopes of the CLC crystallization interface dissolved CLC crystals in mucous derived from an asthma patient and reversed CLC-driven inflammation in a humanized experimental mouse model of asthma [34]. These data suggest that CLC/galectin 10 may be a new drug target in asthma.

Int Arch Allergy Immunol 2020;181:11-23 


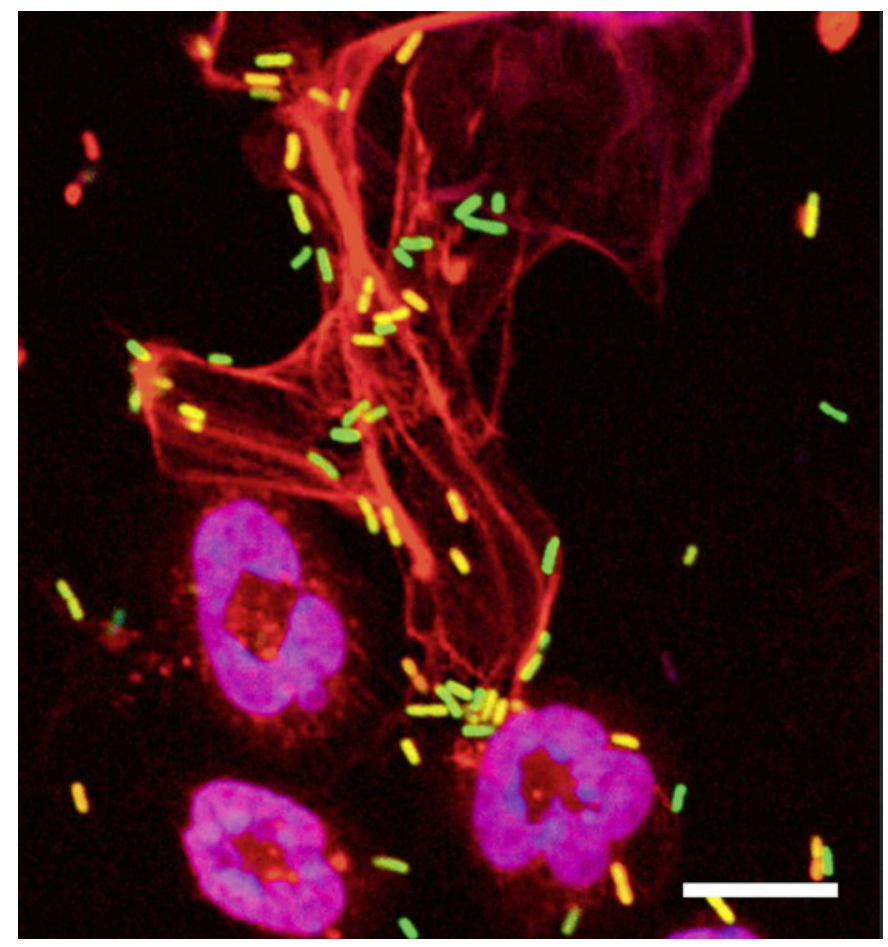

Fig. 2. EET entrap and kill bacteria. Confocal microscopy. E. coli triggers the release of mtDNA and cationic granule proteins from mouse eosinophils. Mouse eosinophils seeded on glass coverslips were primed with GM-CSF for $20 \mathrm{~min}$ and subsequently cocultured with GFP-labelled E. coli (ratio of 1:10) for $15 \mathrm{~min}$. In the final $5 \mathrm{~min}$ of the stimulation period, cells were labelled with $5 \mu \mathrm{M}$ MitoSOX Red to stain the extracellular DNA. Cells were then fixed with $4 \%$ paraformaldehyde and the nucleus was stained with $1 \mu \mathrm{M}$ Hoechst 33342. The image was acquired by LSM 700 (Carl Zeiss Micro Imaging, Jena, Germany) using a ×63/1.40 Oil DIC objective. Scale bar, $10 \mu \mathrm{m}$.

Granule proteins can also be attached to DNA released from activated eosinophils. Such extracellular structures have been designated as eosinophil extracellular traps (EET) [35]. EET are a part of the innate immune response and can be seen in multiple infectious, allergic, and autoimmune eosinophilic diseases. Interestingly, the DNA within the EET appears to have its origin in the mitochondria of eosinophils, which have released fragments of their mitochondrial DNA, but remain viable, exhibiting no evidence of a reduced life span. EET formation does not require cell death and its molecular mechanism is distinct from that of eosinophil cytolysis [29, 35]. Multiple eosinophil activation mechanisms can lead to EET formation (Fig. 1), whereby toll-like, cytokine, chemokine, and adhesion receptors can all initiate transmembrane signal transduction processes leading to the formation of EET $[35,36]$. One of the key signaling events required for
DNA release is the activation of NADPH oxidase [35, 37]. EET are present in allergic, autoimmune, and infectious eosinophilic diseases [35, 38-42].

Much exploration has been directed toward understanding the function of EET. EET capture and kill bacteria (Fig. 2) [35] and fungi [43]. They have also been found to be capable of playing an anti-bacterial role in experimental mouse models under in vivo conditions [35, 44]. Similar extracellular DNA traps are formed by neutrophils and designated neutrophil extracellular traps [45, 46]. As with EET, there is controversy regarding the origin and mechanism of DNA release in neutrophils which has recently been reviewed elsewhere [47]. Neutrophil extracellular traps formed by viable neutrophils require an intact cytoskeleton [48] and mitochondria for glycolytic ATP production [49]. Whether these intracellular mechanisms also hold true for eosinophils remains to be shown. Although autophagy can partially block eosinophil cytolysis [29], it appears that the lack of autophagy does not affect EET formation [50].

\section{Anti-Pathogen Activities of Eosinophils}

Eosinophil numbers are often elevated in the course of helminth infections. In conjunction with the observation that granule proteins such as MBP and ECP exhibit antiparasitic activities under in vitro conditions, the historic view concluded that eosinophils represent important effector cells in helminth infections. However, the role of eosinophils in experimental mouse models of helminth infections often failed to show evidence for an anti-parasitic role [51, 52]. In fact, there is evidence that parasites, at least in the case of Trichinella spiralis, recruit eosinophils to facilitate their own persistence [53]. Likewise, human data collected in endemic countries have also led to the conclusion that ECP has no immediate impact on infection with Schistosoma mansoni [54]. In contrast, more recent data support that eosinophils mediate immunity to filarial tissue helminth infection [55]. Similarly, the lack of eosinophils increased the severity of Litomosoides sigmodontis infection [56]. It is not yet clear why the role of eosinophils in helminthic parasitic infections remains unsettled, but it appears that their function is largely dependent on the mouse strain and pathogen employed [57]. A better understanding of eosinophils as immunomodulatory leukocytes may ultimately help to resolve this complex issue $[20,58]$.

Besides recent studies demonstrating anti-bacterial activities for eosinophils in the context of EET formation,
Simon/Yousefi/Germic/Arnold/Haczku/ Karaulov/Simon/Rosenberg 
earlier studies have highlighted the bactericidal properties of MBP and ECP in vitro. In vivo data seem to support a direct anti-bacterial role of eosinophils, as the adoptive transfer of eosinophils has been found to be sufficient to protect against bacterial septic shock [35, 59]. Moreover, it was recently shown that eosinophils degranulate and form EET in mice infected with Citrobacter rodentium, a model of Escherichia coli infection in humans. In this model, the bacterial infections appeared to be controlled by eosinophils, while in the absence of eosinophils mice suffer from severe bacterial infection and colitis [44]. However, it should be noted that, even in these models, eosinophils may be activating other cells which then result in the indirect protection from bacterial pathogens.

Eosinophils may also exhibit anti-viral activities. For instance, the granule protein eosinophil-derived neurotoxin (EDN) has been shown to have anti-viral activity in vitro [60]. In experimental models, hypereosinophilic mice clear respiratory syncytial virus more effectively than wild-type mice [61], and can prevent infection with the natural rodent pathogen pneumonia virus of mice [62]. This effect seems to be mediated by the release of eosinophil mediators which limit the infection of host epithelial cells [63]. Similarly, in a guinea pig model, allergen-induced eosinophilia has been associated with a decreased viral load during parainfluenza virus infection [64]. Similar findings have been observed in mice infected with Influenza A [65], although anti-viral activity does not occur in all contexts [66]. Taken together, eosinophils, perhaps by the release of soluble mediators, mediate anti-viral effects, but the mechanism needs to be explored and further clarified.

\section{Immunoregulatory Roles of Eosinophils}

Eosinophils produce and release functional cytokines and chemokines. For instance, eosinophils can produce IL-4 [67] and IL-13 [68] which trigger Th2 differentiation [69] and B cell activation [68] and maintain alternatively activated macrophages [70]. In addition, the recruitment of Th2 cells is supported by producing CC chemokine ligand 17 (CCL17) and CCL22 [71]. It should be noted, however, that eosinophils can also produce IFN- $\gamma$ which promotes Th1 responses [72]. On the other hand, eosinophils have recently been shown to restrict Th1 responses against intestinal commensals and in response to experimental Helicobacter pylori infection, suggesting that they actively contribute to the maintenance of intestinal homeostasis [44]. In addition, eosinophils are required for

The Cellular Functions of Eosinophils the maintenance of intestinal IgA+ plasma cells and a normal microbiota composition in a mechanism possibly involving TGF- $\beta$ [73]. Eosinophils also produce APRIL and IL-6, which sustain long-lived plasma cells in the bone marrow [73]. They can also produce and release large amounts of IL-8 [74], GM-CSF [75], and IL-10 [76], suggesting that they might be able to attract neutrophils, autostimulate themselves in an autocrine/paracrine manner, and suppress immune responses. The cytokine expression by eosinophils under in vivo conditions varies substantially and may be disease and microenvironment dependent [77].

Eosinophils can interact with several cell types and release a broad range of soluble mediators in addition to cytokines. For instance, the release of cationic granule proteins stimulates dendritic cells [78], mast cells [79], neutrophils [80], and nerve cells [81]. Granule proteins can also damage epithelial cells [31] which may release damage-associated molecular patterns, hence maintaining the inflammatory state. Eosinophils have also been described as antigen-presenting cells [82], although the in vivo functional relevance of this observation has been questioned [83]. Recent findings also suggest a role for eosinophils in regulating adipose tissue [70], which is now considered as a tertiary lymphoid organ [84]. Eosinophils have been described as being located in proximity to mast cells under in vivo conditions [85]. In vitro data suggest that eosinophils and mast cells signal each with reciprocal surface receptor interactions and with the release of soluble factors (Fig. 3) [86].

Eosinophils along with other structural and immune cells are an abundant source of inducible nitric oxide synthase (iNOS) [87]. By the oxidation of L-arginine to L-citrulline, iNOS synthesizes nitric oxide (NO), an important signaling molecule, neurotransmitter, and host defense and immune regulator [88]. iNOS-derived NO can kill bacteria and has anti-viral effects, but it can also cause severe tissue damage and modulate the function of immune cells by nitration or nitrosylation of key signaling pathway molecules. For instance, in the presence of iNOS, S-nitrosylation of cysteine residues results in deoligomerization of the immunoprotective surfactant protein D (SP-D) and loss of its anti-inflammatory function. Specifically, S-nitrosylated SP-D was no longer able to suppress extracellular DNA trap formation by eosinophils in vitro and in a model of severe eosinophilic airway inflammation in mice in vivo [89]. NO has been shown to alter tyrosine residues in transcription factors, thereby suppressing its own production and the polarization of M1 macrophages as well as Th1 and Th17 cells, providing negative feedback and 


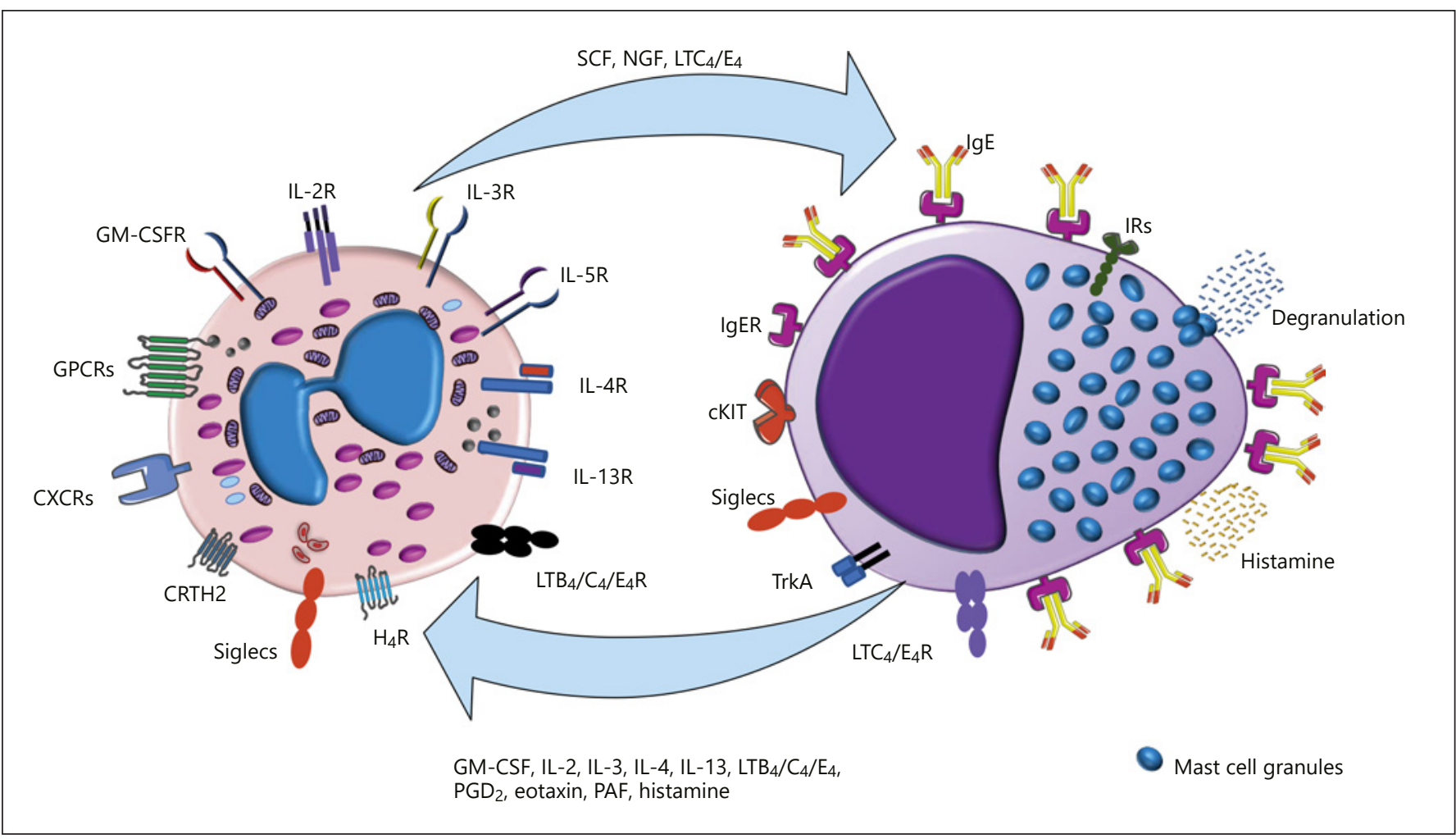

Fig. 3. Eosinophil-mast cell interactions. Schematic representation of interactions between eosinophils and mast cells. Eosinophils release preformed mediators including stem cell factor (SCF), nerve growth factor (NGF), and leukotrienes $\mathrm{C}_{4}$ and $\mathrm{E}_{4}\left(\mathrm{LTC}_{4} / \mathrm{E}_{4}\right)$; these mediators elicit a functional response through activation of specific receptors on mast cells, including c-KIT receptor (CD117), tropomyosin-receptor kinase A (Trak A), and leukotriene receptors $\left(\mathrm{LTC}_{4} \mathrm{R}\right.$ and $\left.\mathrm{LTE}_{4} \mathrm{R}\right)$. Mast cell degranulation promoted by allergens via cross-linking of high-affinity immunoglobulin $\mathrm{E}$ re-

skewing inflammation [90]. Indeed, high levels of iNOSderived $\mathrm{NO}$ are strongly associated with Th2-high airway inflammation in asthma. Accordingly, fractional exhaled $\mathrm{NO}(>50 \mathrm{ppb})$ in the breath of adult patients with asthma, together with peripheral blood eosinophilia, is used as a noninvasive, predictive biomarker identifying those suitable for targeted anti-eosinophil treatment [91].

\section{Adipose Tissue Activation by Eosinophils}

It has been demonstrated that eosinophils are components of adipose tissue infiltrates where they promote glucose homeostasis and regulate energy expenditure [70]. Mice lacking eosinophils display exaggerated weight gain and glucose intolerance when fed a high-calorie diet [70]. In contrast, hypereosinophilic mice show protection from ceptors (FceRI) results in the release of histamine that acts on eosinophils throughhistamine receptor $4\left(\mathrm{HR}_{4}\right)$. Activated mast cells also regulate eosinophil function via the activation of cytokine receptors, leukotriene receptors $\left(\mathrm{LTB}_{4} \mathrm{R}\right.$ and $\left.\mathrm{LTC}_{4} \mathrm{R}\right)$, prostaglandin $\mathrm{D}_{2}\left(\mathrm{PGD}_{2}\right)$ receptor (CRTH2), chemokine receptors (CXCRs), and other G-protein-coupled receptors (GPCRs). Mast cells and eosinophils also maintain inhibitory immunoreceptor tyrosinebased inhibition motif (ITIM)-bearing receptors (IRs) and Siglecs, both of which serve to downregulate immune responses [126].

diet-induced obesity and improved glucose tolerance [70]. Group 2 innate lymphoid cells (ILC2), by releasing IL-5, promote eosinophil accumulation in adipose tissue [92]. Eotaxin-1 is produced by adipocytes which actively recruit eosinophils to adipose tissue [93]. Interestingly, a fibroblast growth factor- 21 analog, which can stimulate eotaxin-1 secretion, was reported to reduce triglycerides and body weight in an early clinical study [93]. The mechanism by which eosinophils regulate the metabolism of adipose tissue may involve the recruitment and longevity of alternatively activated M2 macrophages (Fig. 4) [94].

Recent work suggests that increasing eosinophil numbers with IL-5 does not improve glucose tolerance or reduce the body weight of obese mice [95]. This surprising negative finding stands in contrast to earlier work in which eosinophil numbers were increased by overexpression of IL-5 in T cells [70]. The reason for this discrep-
16

Int Arch Allergy Immunol 2020;181:11-23 DOI: $10.1159 / 000504847$
Simon/Yousefi/Germic/Arnold/Haczku/ Karaulov/Simon/Rosenberg 


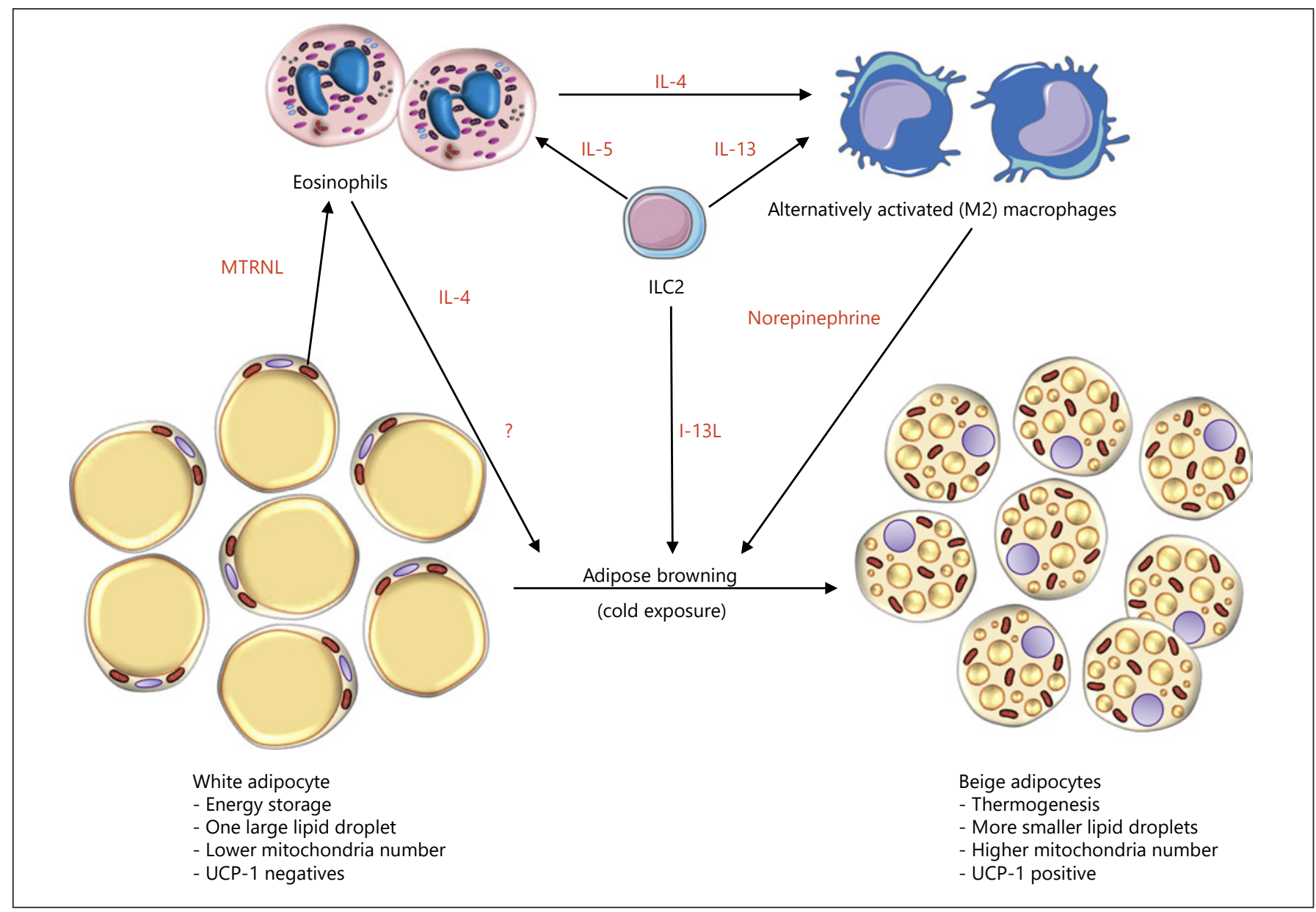

Fig. 4. Eosinophils regulate the metabolism of adipose tissue. Schematic representation of the potential role of eosinophils in adipocyte metabolism. The current view is that IL-33 from resident mesenchyme-derived stromal cells in white adipose tissue activates resident type 2 innate lymphoid cell (ILC2) to produce IL-5 [127]; this cytokine mediator activates eosinophils, which facilitates both chemoattraction and prolonged survival. Activated eosinophils release IL-4, which, together with ILC2, contributes IL-13 and converts tissue resident macrophages to alternatively activated macrophages capable of producing and releasing the norepinephrine re-

ancy remains unclear but may be simply that mice need longer time periods of high IL-5 levels or that levels of eosinophils achieved were not high enough after IL-5 application. Alternatively, several groups have shown that IL-5 overexpression elicits just one of many outcomes and that other eosinophil phenotypes may result depending on which cytokines contributed to differentiation and activation $[96,97]$. Nevertheless, it can be concluded that a simple increase in eosinophil numbers in adipose tissue does not automatically improve its metabolic functions. It seems that the nature and quality of the eosinophils in- quired for adipose browning [128], although the parts of the pathway linking alternatively activated macrophages and norepinephrine to the browning process have recently been questioned [129]. Other data suggest that eosinophils may also interact with adipocytes directly by releasing unknown eosinokines (indicated by the question mark, inferring soluble factors from eosinophils that initiate the browning process). In addition, adipocytes can release meteorin-like peptide (MTRNL), an immunoregulatory cytokine, from muscle and adipose that stimulates eosinophils to secrete IL-4 [130] which initiates the process as indicated above.

filtrating into the tissue are a crucial issue and that further research focused on gene expression, signaling networks, and mediator release is needed to clarify these points.

\section{Wound Healing and Remodeling Mediated by Eosinophils}

When damage-associated molecular patterns are released from damaged cells, eosinophils are activated through their pattern-recognition receptors. Pattern- 
Fig. 5. Anti-eosinophil monoclonal antibodies: targeting the IL-5-IL5R- $\alpha$ axis. Mepolizumab and reslizumab are humanized monoclonal antibodies that target and neutralize circulating IL-5. Both have been approved for clinical use for add-on maintenance treatment of adults with severe eosinophilic asthma. Benralizumab, an antibody in use for similar indications, is directed against the $\alpha$-chain of the IL- 5 receptor (IL-5R) and induces antibody-mediated cellular cytotoxicity (ADCC) in eosinophils, depleting eosinophils both in blood and tissues.

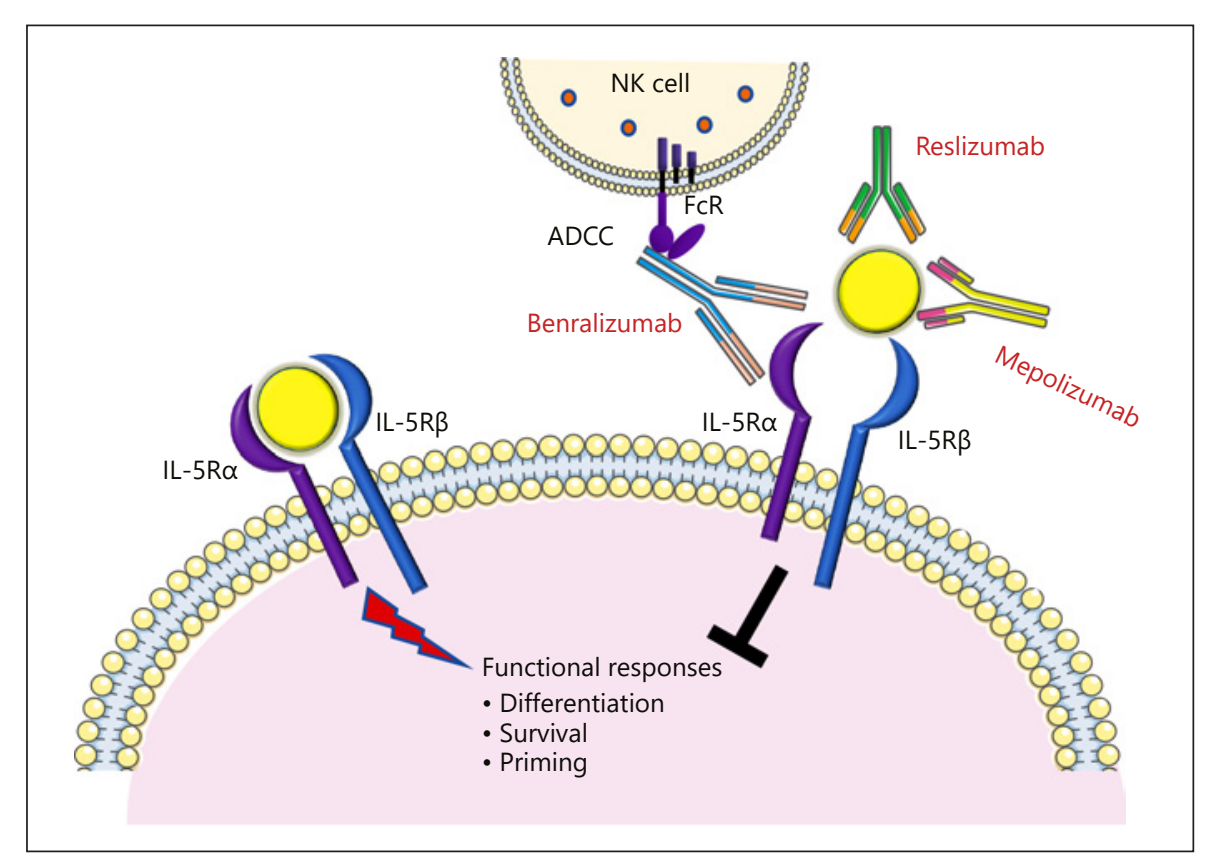

recognition receptors are surface molecules that can recognize pathogens and/or host-derived damage signals [98]. For instance, the binding to high mobility group box-1 (HMGB1), a necrosis signaling molecule, by the receptor for advanced glycation end products (RAGE) expressed on eosinophils can mediate the chemotactic migration of eosinophils and their response to areas of tissue injury or necrosis [99]. Moreover, eosinophils were rapidly recruited following skeletal muscle injury and were required for the proliferation of muscle resident fibro/adipocyte progenitors through secretion of IL-4 [100]. Eosinophils further promote healing by acting on the vasculature and elevating epithelial cell proliferation [101]. For this reason, eosinophils release cytokines such as vascular endothelial growth factor, fibroblast growth factor, and transforming growth factor- $\beta 1$ (TGF- $\left.\beta_{1}\right)$ [58] as well as osteopontin [101].

However, the healing effect mediated by eosinophils is often exaggerated. A fibrogenic process is often observed in chronic inflammatory eosinophilic diseases such as bronchial asthma [102] and eosinophilic esophagitis [103]. A recent study suggested that eosinophilregulated s100a8 and s100a9 participates in tissue healing in an experimental colonic inflammation model [104].

\section{Eosinophil Subpopulations}

Functional distinctions have been drawn between eosinophils recruited from circulation in response to tissue pathology (allergic, parasitic, neoplastic, and immune) and those that maintain residence and are present in tissues at homeostasis. Eosinophils are prominent among the resident cells of the small intestine, and distinct populations of eosinophils have been identified in the mouse lung $[105,106]$. Similar to T cells, B cells, innate lymphoid cells, and dendritic cells, a primary classification system that defines eosinophil subpopulations on the basis of surface antigen expression, tissue localization, content, and function, has recently been presented [107].

It is clear that eosinophils from different sources and unique microenvironments differ in their expression of surface receptors and cytokines [72, 107, 108]. For instance, mouse eosinophils exhibited a proinflammatory gene expression signature that was lost upon initiation of the repair phase [104]. In human subjects, the intestinal mucosa of patients with eosinophil esophagitis included both CD25 positive and negative eosinophils [109]. Furthermore, in eosinophilic skin diseases, populations of eosinophils expressing unique subsets of cytokines were detected [77]. Among normal blood donors, the cytokine content varied significantly, in particular the concentrations of the dual-function cytokine IL-16 [110]. These data suggest that eosinophils are by nature heterogeneous 
and that different eosinophil subpopulations exist in vivo. These findings may thus have an impact on the outcome and efficacy of eosinophil-targeted therapy.

\section{Depletion of Eosinophils by Anti-Eosinophil Therapies}

In recent years, several therapies targeting human eosinophils have been developed. Three humanized monoclonal antibodies that target the IL-5/IL-5 receptor axis are currently available for the treatment of eosinophilic asthma, a subphenotype of asthma that is diagnosed by elevated levels of eosinophils in bronchial biopsies and/or sputum despite appropriate steroid therapy $[111,112]$ (Fig. 5). Two antibodies against IL-5, i.e., mepolizumab and reslizumab, have been approved for add-on treatment of patients with severe eosinophilic asthma [113]. Both antibodies reduce blood eosinophil numbers $[114,115]$ most likely through reduced eosinophil differentiation in the bone marrow and have shown significant reductions in the annualized exacerbation rate and symptomatology compared with placebo [113]. Another therapeutic recently introduced is benralizumab, which is a humanized monoclonal antibody directed against the IL-5 receptor a-chain. This antibody rapidly depletes eosinophils and basophils via antibody-dependent cell-mediated cytotoxicity [116]. Administration of benralizumab to individuals with eosinophilic asthma reduces asthma exacerbation rates and improves lung function [117]. Currently, multiple other clinical trials are being conducted. For instance, targeting eosinophils might also be useful in chronic obstructive pulmonary disease [113], Churg-Strauss syndrome [118], chronic eosinophilic rhinosinusitis [115], and hypereosinophilic syndromes $[4,119]$.

Although all 3 antibodies demonstrated a strong safety profile, long-term studies are needed to evaluate the consequences of long-term eosinophil depletion. While mepolizumab had no apparent impact on physiological infiltration of eosinophils in the intestine [120], such studies have not yet been performed with reslizumab or benralizumab. This is of concern, as a recent study performed in patients with hypereosinophilic syndromes suggested that benralizumab therapy resulted in complete depletion eosinophils from tissues [4]. It is unclear whether elimination of eosinophils to this unprecedented degree leads to alterations in antibody production, metabolism, immune responses against pathogens, or tissue repair. Furthermore, in addition to the IL-5/IL-5 receptor axis, there are multiple other ways to target eosinophils
[121]. Just recently, dupilumab, an antibody that targets the IL-4 receptor a subunit and thus blocks signaling from both IL- 4 and IL-13 has been approved for add-on maintenance therapy in patients with moderate-to-severe eosinophilic asthma [122].

As a final note, several recent studies indicate that strategies developed to deplete eosinophils may have an even broader impact on human health. Specifically, IL-5 expression has been associated with migration and invasion of muscle-invasive bladder cancer cells $[123,124]$ and antibody targeting of the IL- 5 receptor $a$ has been identified as a potential therapeutic strategy [125].

\section{Unmet Needs}

Despite being present in all vertebrates, the physiological role of eosinophils is still unclear. Distinct eosinophil subgroups possibly exert different functions and, as such, the identification of functional subgroups and specific markers is obviously an urgent research objective. Application of proteomics, transcriptomics, and metabolomics to eosinophil biology may help to promote further advances in this field. Likewise, single-cell RNA sequencing may contribute to the definition of eosinophil subpopulations under appropriate in vivo conditions.

Outstanding issues relating to eosinophilic diseases include the role of eosinophils in promoting versus ameliorating disease, i.e., pathogenesis versus immunomodulation and tissue regeneration. The identification of predictors for the efficacy of anti-eosinophil treatments is therefore a key objective and might further result in the identification of new functional eosinophil subsets as well as new categories of eosinophil-associated clinical disorders. Finally, the question of severe adverse effects resulting from long-term and extensive eosinophil depletion needs to be addressed in a definitive fashion.

\section{Acknowledgements}

The authors apologize to investigators whose contributions were not cited because of space limitations. The original work of the authors described here was supported by the Swiss National Science Foundation (grant No. 31003A_173215 to S.Y. and 310030_166473 to H.-U.S.), the European Union Horizon 2020 Research and Innovation Program (Marie Sklodowska-Curie grant No. 642295; MEL-PLEX), the NIAID-Division of Intramural Research (grant No. Z01-AI000941-16 to H.F.R.), the TobaccoRelated Disease Research Program (grant No. TRDRP556126/2018 to A.H.), the NIH (grant No. 2R42AI132012-02 to A.H.), and the Russian Excellence Project 5-100 (to A.K.). 


\section{References}

1 Ehrlich P. Methodologische Beiträge zur Physiologie und Pathologie der verschiedenen Formen der Leukocyten. Z Klin Med. 1880;1:553-60.

2 Lieschke GJ, Oates AC, Crowhurst MO, Ward AC, Layton JE. Morphologic and functional characterization of granulocytes and macrophages in embryonic and adult zebrafish. Blood. 2001 Nov;98(10):3087-96.

3 Stacy NI, Raskin RE. Reptilian eosinophils: beauty and diversity by light microscopy. Vet Clin Pathol. 2015 Jun;44(2):177-8.

4 Kuang FL, Legrand F, Makiya M, Ware J, Wetzler L, Brown T, et al. Benralizumab for PDGFRA-negative hypereosinophilic syndrome. N Engl J Med. 2019 Apr;380(14): 1336-46.

5 Gleich GJ, Klion AD, Lee JJ, Weller PF. The consequences of not having eosinophils. Allergy. 2013 Jul;68(7):829-35.

6 Sanderson CJ. Interleukin-5, eosinophils, and disease. Blood. 1992 Jun;79(12):3101-9.

7 Stoeckle C, Geering B, Yousefi S, Rožman S, Andina N, Benarafa C, et al. RhoH is a negative regulator of eosinophilopoiesis. Cell Death Differ. 2016 Dec;23(12):1961-72.

8 Saito H, Hatake K, Dvorak AM, Leiferman KM, Donnenberg AD, Arai N, et al. Selective differentiation and proliferation of hematopoietic cells induced by recombinant human interleukins. Proc Natl Acad Sci USA. 1988 Apr;85(7):2288-92.

9 McNagny K, Graf T. Making eosinophils through subtle shifts in transcription factor expression. J Exp Med. 2002 Jun;195(11): F43-7.

10 Bettigole SE, Lis R, Adoro S, Lee AH, Spencer LA, Weller PF, et al. The transcription factor $\mathrm{XBP} 1$ is selectively required for eosinophil differentiation. Nat Immunol. 2015 Aug; 16(8):829-37.

11 Ponath PD, Qin S, Ringler DJ, Clark-Lewis I, Wang J, Kassam N, et al. Cloning of the human eosinophil chemoattractant, eotaxin. Expression, receptor binding, and functional properties suggest a mechanism for the selective recruitment of eosinophils. J Clin Invest. 1996 Feb;97(3):604-12.

12 Ponath PD, Qin S, Post TW, Wang J, Wu L, Gerard NP, et al. Molecular cloning and characterization of a human eotaxin receptor expressed selectively on eosinophils. J Exp Med. 1996 Jun;183(6):2437-48.

13 Valent P, Gleich GJ, Reiter A, Roufosse F, Weller PF, Hellmann A, et al. Pathogenesis and classification of eosinophil disorders: a review of recent developments in the field. Expert Rev Hematol. 2012 Apr;5(2):157-76.

14 Carlens J, Wahl B, Ballmaier M, Bulfone-Paus $\mathrm{S}$, Förster R, Pabst O. Common gammachain-dependent signals confer selective survival of eosinophils in the murine small intestine. J Immunol. 2009 Nov;183(9):5600-7.

15 Simon HU, Yousefi S, Schranz C, Schapowal A, Bachert C, Blaser K. Direct demonstration of delayed eosinophil apoptosis as a mechanism causing tissue eosinophilia. J Immunol. 1997 Apr;158(8):3902-8.

16 Simon D, Simon HU. Eosinophilic disorders. J Allergy Clin Immunol. 2007 Jun;119(6): 1291-300.

17 Stoeckle C, Simon HU. CD8(+) T cells producing IL-3 and IL-5 in non-IgE-mediated eosinophilic diseases. Allergy. 2013 Dec; 68(12):1622-5.

18 Lammel V, Stoeckle C, Padberg B, Zweifel R, Kienle DL, Reinhart WH, et al. Hypereosinophilia driven by GM-CSF in large-cell carcinoma of the lung. Lung Cancer. 2012 Jun; 76(3):493-5.

19 Rosenberg HF, Druey KM. Modeling asthma: Pitfalls, promises, and the road ahead. J Leukoc Biol. 2018 Jul;104(1):41-8.

20 Rosenberg HF, Dyer KD, Foster PS. Eosinophils: changing perspectives in health and disease. Nat Rev Immunol. 2013 Jan;13(1):9-22.

21 Lee JJ, Jacobsen EA, Ochkur SI, McGarry MP, Condjella RM, Doyle AD, et al. Human versus mouse eosinophils: "that which we call an eosinophil, by any other name would stain as red”. J Allergy Clin Immunol. 2012 Sep; 130(3):572-84.

22 Doyle AD, Jacobsen EA, Ochkur SI, Willetts L, Shim K, Neely J, et al. Homologous recombination into the eosinophil peroxidase locus generates a strain of mice expressing Cre recombinase exclusively in eosinophils. J Leukoc Biol. 2013 Jul;94(1):17-24.

23 O'Sullivan JA, Bochner BS. Eosinophils and eosinophil-associated diseases: an update. J Allergy Clin Immunol. 2018 Feb;141(2):50517.

24 Melo RC, Weller PF. Piecemeal degranulation in human eosinophils: a distinct secretion mechanism underlying inflammatory responses. Histol Histopathol. 2010 Oct;25(10): 1341-54.

25 Simon HU, Weber M, Becker E, Zilberman Y, Blaser K, Levi-Schaffer F. Eosinophils maintain their capacity to signal and release eosinophil cationic protein upon repetitive stimulation with the same agonist. J Immunol. 2000 Oct;165(7):4069-75.

26 Uller L, Andersson M, Greiff L, Persson CG, Erjefält JS. Occurrence of apoptosis, secondary necrosis, and cytolysis in eosinophilic nasal polyps. Am J Respir Crit Care Med. 2004 Oct;170(7):742-7.

27 Saffari H, Hoffman LH, Peterson KA, Fang JC, Leiferman KM, Pease LF 3rd, et al. Electron microscopy elucidates eosinophil degranulation patterns in patients with eosinophilic esophagitis. J Allergy Clin Immunol. 2014 Jun;133(6):1728-34.e1.

28 Erjefält JS, Andersson M, Greiff L, Korsgren M, Gizycki M, Jeffery PK, et al. Cytolysis and piecemeal degranulation as distinct modes of activation of airway mucosal eosinophils. J Allergy Clin Immunol. 1998 Aug;102(2):28694.
29 Radonjic-Hoesli S, Wang X, de Graauw E, Stoeckle C, Styp-Rekowska B, Hlushchuk R, et al. Adhesion-induced eosinophil cytolysis requires the receptor-interacting protein kinase 3 (RIPK3)-mixed lineage kinase-like (MLKL) signaling pathway, which is counterregulated by autophagy. J Allergy Clin Immunol. 2017 Dec;140(6):1632-42.

30 Wright BL, Leiferman KM, Gleich GJ. Eosinophil granule protein localization in eosinophilic endomyocardial disease. $N$ Engl J Med. 2011 Jul;365(2):187-8

31 Soragni A, Yousefi S, Stoeckle C, Soriaga AB, Sawaya MR, Kozlowski E, et al. Toxicity of eosinophil MBP is repressed by intracellular crystallization and promoted by extracellular aggregation. Mol Cell. 2015 Mar;57(6):101121.

32 Olsson I, Venge P, Spitznagel JK, Lehrer RI. Arginine-rich cationic proteins of human eosinophil granules: comparison of the constituents of eosinophilic and neutrophilic leukocytes. Lab Invest. 1977 May;36(5):493-500.

33 Pantanowitz L, Balogh K. Charcot-Leyden crystals: pathology and diagnostic utility. Ear Nose Throat J. 2004 Jul;83(7):489-90.

34 Persson EK, Verstraete K, Heyndrickx I, Gevaert E, Aegerter H, Percier JM, et al. Protein crystallization promotes type 2 immunity and is reversible by antibody treatment. Science. 2019 May;364(6442):4295.

35 Yousefi S, Gold JA, Andina N, Lee JJ, Kelly AM, Kozlowski E, et al. Catapult-like release of mitochondrial DNA by eosinophils contributes to antibacterial defense. Nat Med. 2008 Sep;14(9):949-53.

36 Morshed M, Yousefi S, Stöckle C, Simon HU, Simon D. Thymic stromal lymphopoietin stimulates the formation of eosinophil extracellular traps. Allergy. 2012 Sep;67(9):112737.

37 Morshed M, Hlushchuk R, Simon D, Walls AF, Obata-Ninomiya K, Karasuyama $H$, et al. NADPH oxidase-independent formation of extracellular DNA traps by basophils. J Immunol. 2014 Jun;192(11):5314-23.

38 Dworski R, Simon HU, Hoskins A, Yousefi S. Eosinophil and neutrophil extracellular DNA traps in human allergic asthmatic airways. J Allergy Clin Immunol. 2011 May;127(5): 1260-6.

39 Simon D, Hoesli S, Roth N, Staedler S, Yousefi S, Simon HU. Eosinophil extracellular DNA traps in skin diseases. J Allergy Clin Immunol. 2011 Jan;127(1):194-9.

40 Simon D, Radonjic-Hösli S, Straumann A, Yousefi S, Simon HU. Active eosinophilic esophagitis is characterized by epithelial barrier defects and eosinophil extracellular trap formation. Allergy. 2015 Apr;70(4): 443-52.

41 de Graauw E, Sitaru C, Horn M, Borradori L, Yousefi S, Simon HU, et al. Evidence for a role of eosinophils in blister formation in bullous pemphigoid. Allergy. 2017 Jul;72(7):1105-13. 
42 Gevaert E, Zhang N, Krysko O, Lan F, Holtappels G, De Ruyck N, et al. Extracellular eosinophilic traps in association with Staphylococcus aureus at the site of epithelial barrier defects in patients with severe airway inflammation. J Allergy Clin Immunol. 2017 Jun; 139(6):1849-1860.e6

43 Muniz VS, Silva JC, Braga YA, Melo RC, Ueki S, Takeda M, et al. Eosinophils release extracellular DNA traps in response to Aspergillus fumigatus. J Allergy Clin Immunol. $2018 \mathrm{Feb}$; 141(2):571-585.e7.

44 Arnold IC, Artola-Borán M, Tallón de Lara P, Kyburz A, Taube C, Ottemann K, et al. Eosinophils suppress Th1 responses and restrict bacterially induced gastrointestinal inflammation. J Exp Med. 2018 Aug;215(8):205572.

45 Brinkmann V, Reichard U, Goosmann C, Fauler B, Uhlemann Y, Weiss DS, et al. Neutrophil extracellular traps kill bacteria. Science. 2004 Mar;303(5663):1532-5.

46 Yousefi S, Mihalache C, Kozlowski E, Schmid I, Simon HU. Viable neutrophils release mitochondrial DNA to form neutrophil extracellular traps. Cell Death Differ. 2009 Nov 16(11):1438-44.

47 Yousefi S, Stojkov D, Germic N, Simon D, Wang X, Benarafa C, et al. Untangling "NETosis" from NETs. Eur J Immunol. $2019 \mathrm{Feb}$ 49(2):221-7.

48 Stojkov D, Amini P, Oberson K, Sokollik C, Duppenthaler A, Simon HU, et al. ROS and glutathionylation balance cytoskeletal dynamics in neutrophil extracellular trap formation. J Cell Biol. 2017 Dec;216(12):407390.

49 Amini P, Stojkov D, Felser A, Jackson CB Courage C, Schaller A, et al. Neutrophil extracellular trap formation requires OPA1-dependent glycolytic ATP production. Nat Commun. 2018 Jul;9(1):2958.

50 Germic N, Stojkov D, Oberson K, Yousefi S, Simon HU. Neither eosinophils nor neutrophils require ATG5-dependent autophagy for extracellular DNA trap formation. Immunology. 2017 Nov;152(3):517-25.

51 Sher A, Coffman RL, Hieny S, Cheever AW. Ablation of eosinophil and IgE responses with anti-IL-5 or anti-IL-4 antibodies fails to affect immunity against Schistosoma mansoni in the mouse. J Immunol. 1990 Dec;145(11): 3911-6.

52 Swartz JM, Dyer KD, Cheever AW, Ramalingam T, Pesnicak L, Domachowske JB, et al. Schistosoma mansoni infection in eosinophil lineage-ablated mice. Blood. 2006 Oct;108(7): 2420-7.

53 Fabre V, Beiting DP, Bliss SK, Gebreselassie NG, Gagliardo LF, Lee NA, et al. Eosinophil deficiency compromises parasite survival in chronic nematode infection. J Immunol. 2009 Feb;182(3):1577-83

54 Eriksson J, Reimert CM, Kabatereine NB, Kazibwe $\mathrm{F}$, Ireri $\mathrm{E}$, Kadzo $\mathrm{H}$, et al. The $434(\mathrm{G}[\{\mathrm{GT}\}] \mathrm{C})$ polymorphism within the coding sequence of Eosinophil Cationic Pro- tein (ECP) correlates with the natural course of Schistosoma mansoni infection. Int J Parasitol. 2007 Oct;37(12):1359-66.

55 Turner JD, Pionnier N, Furlong-Silva J, Sjoberg $\mathrm{H}$, Cross S, Halliday A, et al. Interleukin-4 activated macrophages mediate immunity to filarial helminth infection by sustaining CCR3-dependent eosinophilia. PLoS Pathog. 2018 Mar;14(3):e1006949.

56 Frohberger SJ, Ajendra J, Surendar J, Stamminger W, Ehrens A, Buerfent BC, et al. Susceptibility to L. sigmodontis infection is highest in animals lacking IL-4R/IL-5 compared to single knockouts of IL-4R, IL-5 or eosinophils. Parasit Vectors. 2019 May;12(1):248.

57 Klion AD, Nutman TB. The role of eosinophils in host defense against helminth parasites. J Allergy Clin Immunol. 2004 Jan; 113(1):30-7.

58 Lee JJ, Jacobsen EA, McGarry MP, Schleimer RP, Lee NA. Eosinophils in health and disease: the LIAR hypothesis. Clin Exp Allergy. 2010 Apr;40(4):563-75.

59 Linch SN, Kelly AM, Danielson ET, Pero R, Lee JJ, Gold JA. Mouse eosinophils possess potent antibacterial properties in vivo. Infect Immun. 2009 Nov;77(11):4976-82.

60 Rugeles MT, Trubey CM, Bedoya VI, Pinto LA, Oppenheim JJ, Rybak SM, et al. Ribonuclease is partly responsible for the HIV-1 inhibitory effect activated by HLA alloantigen recognition. AIDS. 2003 Mar;17(4):481-6.

61 Phipps S, Lam CE, Mahalingam S, Newhouse M, Ramirez R, Rosenberg HF, et al. Eosinophils contribute to innate antiviral immunity and promote clearance of respiratory syncytial virus. Blood. 2007 Sep;110(5):1578-86.

62 Percopo CM, Dyer KD, Ochkur SI, Luo JL, Fischer ER, Lee JJ, et al. Activated mouse eosinophils protect against lethal respiratory virus infection. Blood. 2014 Jan;123(5):743-52.

63 Domachowske JB, Dyer KD, Bonville CA, Rosenberg HF. Recombinant human eosinophil-derived neurotoxin/RNase 2 functions as an effective antiviral agent against respiratory syncytial virus. J Infect Dis. 1998 Jun;177(6): 1458-64.

64 Adamko DJ, Yost BL, Gleich GJ, Fryer AD, Jacoby DB. Ovalbumin sensitization changes the inflammatory response to subsequent parainfluenza infection. Eosinophils mediate airway hyperresponsiveness, $\mathrm{m}(2)$ muscarinic receptor dysfunction, and antiviral effects. J Exp Med. 1999 Nov;190(10):1465-78.

65 Samarasinghe AE, Melo RC, Duan S, LeMessurier KS, Liedmann S, Surman SL, et al. Eosinophils promote antiviral immunity in mice infected with influenza A virus. J Immunol. 2017 Apr;198(8):3214-26.

66 Ma M, Redes JL, Percopo CM, Druey KM, Rosenberg HF. Alternaria alternata challenge at the nasal mucosa results in eosinophilic inflammation and increased susceptibility to influenza virus infection. Clin Exp Allergy. 2018 Jun;48(6):691-702.

67 Spencer LA, Melo RC, Perez SA, Bafford SP, Dvorak AM, Weller PF. Cytokine receptor- mediated trafficking of preformed IL-4 in eosinophils identifies an innate immune mechanism of cytokine secretion. Proc Natl Acad Sci USA. 2006 Feb;103(9):3333-8.

68 Schmid-Grendelmeier P, Altznauer F, Fischer B, Bizer C, Straumann A, Menz G, et al. Eosinophils express functional IL-13 in eosinophilic inflammatory diseases. J Immunol. 2002 Jul;169(2):1021-7.

69 Walsh ER, Thakar J, Stokes K, Huang F, Albert R, August A. Computational and experimental analysis reveals a requirement for eosinophil-derived IL-13 for the development of allergic airway responses in C57BL/6 mice. J Immunol. 2011 Mar;186(5):2936-49.

70 Wu D, Molofsky AB, Liang HE, Ricardo-Gonzalez RR, Jouihan HA, Bando JK, et al. Eosinophils sustain adipose alternatively activated macrophages associated with glucose homeostasis. Science. 2011 Apr;332(6026):243-7.

71 Jacobsen EA, Ochkur SI, Pero RS, Taranova AG, Protheroe CA, Colbert DC, et al. Allergic pulmonary inflammation in mice is dependent on eosinophil-induced recruitment of effector T cells. J Exp Med. 2008 Mar;205(3): 699-710.

72 Spencer LA, Szela CT, Perez SA, Kirchhoffer CL, Neves JS, Radke AL, et al. Human eosinophils constitutively express multiple Th1, Th2, and immunoregulatory cytokines that are secreted rapidly and differentially. J Leukoc Biol. 2009 Jan;85(1):117-23.

73 Chu VT, Fröhlich A, Steinhauser G, Scheel T, Roch T, Fillatreau S, et al. Eosinophils are required for the maintenance of plasma cells in the bone marrow. Nat Immunol. $2011 \mathrm{Feb}$; 12(2):151-9.

74 Yousefi S, Hemmann S, Weber M, Hölzer C, Hartung K, Blaser K, et al. IL-8 is expressed by human peripheral blood eosinophils. Evidence for increased secretion in asthma. J Immunol. 1995 May;154(10):5481-90.

75 Kita H, Ohnishi T, Okubo Y, Weiler D, Abrams JS, Gleich GJ. Granulocyte/macrophage colony-stimulating factor and interleukin 3 release from human peripheral blood eosinophils and neutrophils. J Exp Med. 1991 Sep;174(3):745-8.

76 Nakajima H, Gleich GJ, Kita H. Constitutive production of IL-4 and IL-10 and stimulated production of IL-8 by normal peripheral blood eosinophils. J Immunol. 1996 Jun; 156(12):4859-66.

77 Roth N, Städler S, Lemann M, Hösli S, Simon HU, Simon D. Distinct eosinophil cytokine expression patterns in skin diseases - the possible existence of functionally different eosinophil subpopulations. Allergy. 2011 Nov; 66(11):1477-86.

78 Lotfi R, Lotze MT. Eosinophils induce DC maturation, regulating immunity. J Leukoc Biol. 2008 Mar;83(3):456-60.

79 O'Donnell MC, Ackerman SJ, Gleich GJ, Thomas LL. Activation of basophil and mast cell histamine release by eosinophil granule major basic protein. J Exp Med. 1983 Jun; 157(6):1981-91. 
80 Moy JN, Gleich GJ, Thomas LL. Noncytotoxic activation of neutrophils by eosinophil granule major basic protein. Effect on superoxide anion generation and lysosomal enzyme release. J Immunol. 1990 Oct;145(8):2626-32.

81 Morgan RK, Costello RW, Durcan N, Kingham PJ, Gleich GJ, McLean WG, et al. Diverse effects of eosinophil cationic granule proteins on IMR-32 nerve cell signaling and survival. Am J Respir Cell Mol Biol. 2005 Aug;33(2): 169-77.

82 Weller PF, Rand TH, Barrett T, Elovic A, Wong DT, Finberg RW. Accessory cell function of human eosinophils. HLA-DR-dependent, MHC-restricted antigen-presentation and IL-1 alpha expression. J Immunol. 1993 Mar;150(6):2554-62.

83 Kambayashi T, Laufer TM. Atypical MHC class II-expressing antigen-presenting cells: can anything replace a dendritic cell? Nat Rev Immunol. 2014 Nov; 14(11):719-30.

84 Frasca D, Blomberg BB. Adipose tissue: a tertiary lymphoid organ - does it change with age? Gerontology. 2019 Aug 14:1-8.

85 Otani IM, Anilkumar AA, Newbury RO, Bhagat M, Beppu LY, Dohil R, et al. Anti-IL-5 therapy reduces mast cell and IL-9 cell numbers in pediatric patients with eosinophilic esophagitis. J Allergy Clin Immunol. 2013 Jun;131(6):1576-82.

86 Galdiero MR, Varricchi G, Seaf M, Marone G, Levi-Schaffer F, Marone G. Bidirectional mast cell-eosinophil interactions in inflammatory disorders and cancer. Front Med (Lausanne). 2017 Jul;4:103.

87 Yancey SW, Keene ON, Albers FC, Ortega H, Bates S, Bleecker ER, et al. Biomarkers for severe eosinophilic asthma. J Allergy Clin Immunol. 2017 Dec;140(6):1509-18.

88 Cinelli MA, Do HT, Miley GP, Silverman RB Inducible nitric oxide synthase: regulation, structure, and inhibition. Med Res Rev. Forthcoming 2019.

89 Yousefi S, Sharma SK, Stojkov D, Germic N, Aeschlimann S, Ge MQ, et al. Oxidative damage of SP-D abolishes control of eosinophil extracellular DNA trap formation. J Leukoc Biol. 2018 Jul;104(1):205-14

90 Xue Q, Yan Y, Zhang R, Xiong H. Regulation of iNOS on immune cells and its role in diseases. Int J Mol Sci. 2018 Nov; 19(12):E3805.

91 Diamant Z, Vijverberg S, Alving K, Bakirtas A, Bjermer L, Custovic A, et al. Toward clinically applicable biomarkers for asthma: an EAACI position paper. Allergy. 2019 Oct; 74(10):1835-51.

92 Molofsky AB, Nussbaum JC, Liang HE, Van Dyken SJ, Cheng LE, Mohapatra A, et al. Innate lymphoid type 2 cells sustain visceral adipose tissue eosinophils and alternatively activated macrophages. J Exp Med. 2013 Mar; 210(3):535-49.

93 Huang Z, Zhong L, Lee JT, Zhang J, Wu D, Geng L, et al. The FGF21-CCL11 axis mediates beiging of white adipose tissues by coupling sympathetic nervous system to type $2 \mathrm{immu}$ nity. Cell Metab. 2017 Sep;26(3):493-508.e4.
94 Qiu Y, Nguyen KD, Odegaard JI, Cui X, Tian $\mathrm{X}$, Locksley RM, et al. Eosinophils and type 2 cytokine signaling in macrophages orchestrate development of functional beige fat. Cell. 2014 Jun;157(6):1292-308.

95 Bolus WR, Peterson KR, Hubler MJ, Kennedy AJ, Gruen ML, Hasty AH. Elevating adipose eosinophils in obese mice to physiologically normal levels does not rescue metabolic impairments. Mol Metab. 2018 Feb;8:86-95.

96 Esnault S, Kelly EA, Shen ZJ, Johansson MW, Malter JS, Jarjour NN. IL-3 maintains activation of the p9056K/RPS6 pathway and increases translation in human eosinophils. J Immunol. 2015 Sep;195(6):2529-39.

97 Geslewitz WE, Percopo CM, Rosenberg HF. Eosinophil persistence in vivo and sustained viability ex vivo in response to respiratory challenge with fungal allergens. Clin Exp Allergy. 2018 Jan;48(1):29-38.

98 Kvarnhammar AM, Cardell LO. Patternrecognition receptors in human eosinophils. Immunology. 2012 May;136(1):11-20.

99 Lotfi R, Herzog GI, DeMarco RA, Beer-Stolz D, Lee JJ, Rubartelli A, et al. Eosinophils oxidize damage-associated molecular pattern molecules derived from stressed cells. J Immunol. 2009 Oct;183(8):5023-31.

100 Heredia JE, Mukundan L, Chen FM, Mueller AA, Deo RC, Locksley RM, et al. Type 2 innate signals stimulate fibro/adipogenic progenitors to facilitate muscle regeneration. Cell. 2013 Apr;153(2):376-88.

101 Puxeddu I, Berkman N, Ribatti D, Bader R Haitchi HM, Davies DE, et al. Osteopontin is expressed and functional in human eosinophils. Allergy. 2010 Feb;65(2):168-74.

102 Bousquet J, Chanez P, Lacoste JY, Barnéon G, Ghavanian N, Enander I, et al. Eosinophilic inflammation in asthma. N Engl J Med. 1990 Oct;323(15):1033-9.

103 Straumann A, Spichtin HP, Grize L, Bucher KA, Beglinger C, Simon HU. Natural history of primary eosinophilic esophagitis: a follow-up of 30 adult patients for up to 11.5 years. Gastroenterology. $2003 \mathrm{Dec}$; 125(6):1660-9.

104 Reichman H, Moshkovits I, Itan M, Pasmanik-Chor M, Vogl T, Roth J, et al. Transcriptome profiling of mouse colonic eosinophils reveals a key role for eosinophils in the induction of s100a8 and s100a9 in mucosal healing. Sci Rep. 2017 Aug;7(1):7117.

105 Weller PF, Spencer LA. Functions of tissueresident eosinophils. Nat Rev Immunol. 2017 Dec;17(12):746-60.

106 Marichal T, Mesnil C, Bureau F. Homeostatic eosinophils: characteristics and functions. Front Med (Lausanne). 2017 Jul;4:101.

107 Abdala-Valencia H, Coden ME, Chiarella SE, Jacobsen EA, Bochner BS, Lee JJ, et al. Shaping eosinophil identity in the tissue contexts of development, homeostasis, and disease. J Leukoc Biol. 2018 Jul;104(1):95-108.

108 Johansson MW. Activation states of blood eosinophils in asthma. Clin Exp Allergy. 2014 Apr;44(4):482-98
109 Straumann A, Kristl J, Conus S, Vassina E, Spichtin HP, Beglinger C, et al. Cytokine expression in healthy and inflamed mucosa: probing the role of eosinophils in the digestive tract. Inflamm Bowel Dis. 2005 Aug; 11(8):720-6.

110 Ma M, Percopo CM, Sturdevant DE, Sek AC, Komarow HD, Rosenberg HF. Cytokine diversity in human peripheral blood eosinophils: profound variability of IL-16. J Immunol. 2019 Jul;203(2):520-31.

111 McDowell PJ, Heaney LG. Different endotypes and phenotypes drive the heterogeneity in severe asthma. Allergy. Forthcomming 2019.

112 de Groot JC, Ten Brinke A, Bel EH. Management of the patient with eosinophilic asthma: a new era begins. ERJ Open Res. 2015 Sep;1(1):00024-2015.

113 Bel EH, Ten Brinke A. New anti-eosinophil drugs for asthma and COPD: targeting the trait! Chest. 2017 Dec;152(6):1276-82.

114 Plötz SG, Simon HU, Darsow U, Simon D, Vassina E, Yousefi S, et al. Use of an antiinterleukin-5 antibody in the hypereosinophilic syndrome with eosinophilic dermatitis. N Engl J Med. 2003 Dec;349(24):2334-9.

115 Gevaert P, Lang-Loidolt D, Lackner A, Stammberger H, Staudinger H, Van Zele T, et al. Nasal IL-5 levels determine the response to anti-IL-5 treatment in patients with nasal polyps. J Allergy Clin Immunol. 2006 Nov;118(5):1133-41.

116 Laviolette M, Gossage DL, Gauvreau G, Leigh R, Olivenstein R, Katial R, et al. Effects of benralizumab on airway eosinophils in asthmatic patients with sputum eosinophilia. J Allergy Clin Immunol. 2013 Nov; 132(5):1086-1096.e5.

117 Casale TB, Pacou M, Mesana L, Farge G, Sun SX, Castro M. Reslizumab compared with benralizumab in patients with eosinophilic asthma: A systematic literature review and network meta-analysis. J Allergy Clin Immunol Pract. 2019 Jan;7(1):122-130.e1.

118 Wechsler ME, Akuthota P, Jayne D, Khoury P, Klion A, Langford CA, et al.; EGPA Mepolizumab Study Team. Mepolizumab or placebo for eosinophilic granulomatosis with polyangiitis. N Engl J Med. 2017 May; 376(20):1921-32.

119 Rothenberg ME, Klion AD, Roufosse FE, Kahn JE, Weller PF, Simon HU, et al.; Mepolizumab HES Study Group. Treatment of patients with the hypereosinophilic syndrome with mepolizumab. N Engl J Med. 2008 Mar;358(12):1215-28.

120 Kuang FL, Legrand F, Makiya M, Ware J, Wetzler L, Brown T, et al. Benralizumab for PDGFRA-negative hypereosinophilic syndrome. N Engl J Med. 2019 Apr;380(14): 1336-46.

121 Radonjic-Hoesli S, Valent P, Klion AD, Wechsler ME, Simon HU. Novel targeted therapies for eosinophil-associated diseases and allergy. Annu Rev Pharmacol Toxicol. 2015;55(1):633-56. 
122 Busse WW, Maspero JF, Rabe KF, Papi A, Wenzel SE, Ford LB, et al. Liberty Asthma QUEST: Phase 3 randomized, double-blind, placebo-controlled, parallel-group study to evaluate dupilumab efficacy/safety in patients with uncontrolled, moderate-to-severe asthma. Adv Ther. 2018 May;35(5): 737-48.

123 Lee SJ, Lee EJ, Kim SK, Jeong P, Cho YH, Yun SJ, et al. Identification of pro-inflammatory cytokines associated with muscle invasive bladder cancer; the roles of IL-5, IL20, and IL-28A. PLoS One. 2012;7(9):e40267.

124 Lee EJ, Lee SJ, Kim S, Cho SC, Choi YH, Kim WJ, et al. Interleukin-5 enhances the migration and invasion of bladder cancer cells via ERK1/2-mediated MMP-9/NF- $\kappa \mathrm{B} / \mathrm{AP}-1$ pathway: involvement of the p21WAF1 expression. Cell Signal. 2013 Oct;25(10):2025-38.

125 Paquette M, Vilera-Perez LG, Beaudoin S, Ekindi-Ndongo N, Boudreaut PL, Bonin MA, et al. Targeting IL-5R $\alpha$ with antibodyconjugates reveals a strategy for imaging and therapy for invasive bladder cancer. OncoImmunology. 2017 May;6(10):e1331195.

126 Shik D, Munitz A. Regulation of allergic inflammatory responses by inhibitory receptors. Clin Exp Allergy. 2010 May;40(5):700-9.

127 Mahlakõiv T, Flamar AL, Johnston LK, Moriyama S, Putzel GG, Bryce PJ, et al. Stromal cells maintain immune cell homeostasis in adipose tissue via production of interleukin-33. Sci Immunol. 2019 May;4(35):eaax0416.
128 Nguyen KD, Qiu Y, Cui X, Goh YP, Mwangi J, David T, et al. Alternatively activated macrophages produce catecholamines to sustain adaptive thermogenesis. Nature. 2011 Nov; 480(7375):104-8.

129 Fischer K, Ruiz HH, Jhun K, Finan B, Oberlin DJ, van der Heide V, et al. Alternatively activated macrophages do not synthesize catecholamines or contribute to adipose tissue adaptive thermogenesis. Nat Med. 2017 May;23(5):623-30.

130 Rao RR, Long JZ, White JP, Svensson KJ, Lou J, Lokurkar I, et al. Meteorin-like is a hormone that regulates immune-adipose interactions to increase beige fat thermogenesis. Cell. 2014 Jun;157(6):1279-91. 